\title{
Global Liquidity Determinants Across Emerging and Advanced Countries
}

\author{
Renata Karkowska ${ }^{1}$ \\ Faculty of Management \\ University of Warsaw, Poland \\ Email: rkarkowska@wz.uw.edu.pl
}

\begin{abstract}
The paper explores the concept of global liquidity and its determinants, focusing on the banking system in advanced and emerging markets. We explore the implications of the interaction between liquidity and its local, global and financial markets determinants. We also analyze the global liquidity channels, i.e. whether foreign banks play a significant role in the country's financial system. The study focuses on the investigation of banks' liquidity determinants in 42 countries (advanced and emerging/developing countries) over the 2000-2011 period. The results show the significance of the differences in global liquidity depending on the country's level of development. We find support to the conjecture that globalization and global banks' leverage may convey some useful information on global liquidity. We also present an important observation that banks' lending in advanced countries is shielded from the monetary policy because of their ability to freely access alternative sources of funds.
\end{abstract}

JEL classification: E5, E44, G20, F3

Keywords: global liquidity, emerging countries, credit supply, financial instability

\section{INTRODUCTION}

The problem of global liquidity has been a popular concept in scientific research and political debate for a long time, but its weight varies significantly over time. In the context of the 2008-2009 financial crisis, the global lack of liquidity has been identified as a potentially important factor resulting from the accumulation of economic imbalances. This issue was particularly important for emerging countries, where after the transformation of the economy, the banking sector is dominated by global financial groups owned by foreign entities. During the past two decades, the Central and Eastern European (CEE) financial systems experienced changes, including their opening to attract foreign investments, mainly big banking groups. The liquidity problem in international financial groups caused by the 2007-2008 crisis also intensified in the banking sectors of emerging/developing countries (Karkowska, 2013). An interesting question is also how the deleveraging of global banks influences liquidity in emerging economies.

Corresponding author: Renata Karkowska, Faculty of Management, University of Warsaw, Szturmowa Street 1/3, 02-678 Warsaw, Poland; email rkarkowska@wz.uw.edu.pl. 
Traditional empirical studies show changes in liquidity conditions based on selected global monetary aggregates (i.e. the size of available credit in the banks), but they also emphasize the cross-border credit amount, which is a significant source of funding for many economies and can be an important source of the banking sector vulnerability to a global financial crisis. The literature also highlights the price of financial instruments as a base for global liquidity indicators, particularly changes in short and long-term interest rates in the money and capital markets or implied market volatility (VIX-index). The latter is a key measure of investors' willingness to take risks in the financial market. Other, more sophisticated measures are based on changes in leverage ratios or the funding gap used by commercial banks.

Banking liquidity has been a subject of international research and the central bank policy over last years. Its drivers are major determinants of financial stability. The literature review has not provided any clear conclusions on the factors affecting the global liquidity of banks. The ongoing processes of globalization mean that more and more developments in financial markets depend on factors not directly resulting from the foundations of the economy, and this is dictated by the changing expectations and investor sentiment on international markets. In order to capture these changes, it is important to use advanced statistical tools. An econometric model testing the association between liquidity and its determinants has been applied.

Given the above doubts, the aim of the study is a multi-faceted analysis of various determinants of global liquidity in emerging, especially Central and Eastern European, and advanced countries in the global scale. At least a few reasons exist why research in this direction should be intensified: (i) globalization and financial integration have a growing impact on domestic financial assets and the dynamics of credit supply in each economy; (ii) banking liquidity shortages have major implications for the economic growth; (iii) global market liquidity can build up the systemic vulnerability across countries.

Our main findings are as follows. First, global liquidity conditions cannot be assessed based on a single indicator in all countries. Second, the liquidity in emerging markets is significantly determined by globalization factors and the leverage of global banks. Monetary policy has not a significant influence on liquidity across countries. The liquidity dynamics is insignificantly dependent on macroeconomic factors. On the other hand, financial market drivers and risk aversion affect liquidity, but mainly in advanced countries.

The paper is organized as follows: Section 2 includes literature review and a conceptual framework for banking liquidity. Section 3 discusses key concepts of liquidity drivers and transmission channels. Section 4 presents data and methodology. Section 5 proposes the global liquidity model and the last section includes results and conclusions.

\section{BACKGROUND AND LITERATURE REVIEW}

The accommodating monetary policy is often accused of creating surplus liquidity on the financial markets. In particular, it could have contributed to strong capital inflows in emerging countries, affecting local financing conditions and increasing liquidity risk in the banking sector. There is a debate whether global liquidity reflects supply or demand factors. On the supply side, loose monetary policy in the major economies is sometimes seen as a driver of growing liquidity (Rüffer and Stracca, 2006). Anderson (2007) argues that the global economy has recorded a decrease in money demand. In addition, Artus and Virard (2010), Darius and Radde (2010) have proxied global liquidity as foreign-exchange reserves and money reserves. The increase of global liquidity is likely to be associated with a rise in aggregate demand.

Non-monetary approaches argue that growing imbalances in capital markets are mainly driven by saving and investment decisions. An increase in savings (also as part of the monetary policy), especially in emerging countries, is one main liquidity driver identified by Bernanke (2005). 
It seems that despite its widespread use, the concept of global liquidity still lacks an agreed definition. Traditional studies have measured global liquidity based on some aggregates as broad money. D'Agostino and Surico (2009), Bruno and Shin (2012) proposed credit as an alternative measure of global liquidity. Credit aggregates are characterized as the final link in the financial intermediation chain and the source of liquidity. Specifically, credit is seen as the availability of liquidity in funding markets. At the same time the ease of assets transforming into liquidity during sale transactions is indicated as assets liquidity on the capital market. Ciccarelli et. al. (2010) and Kose et al. (2003) have measured global liquidity based on the common factors in the dynamics of a large number of quantitative liquidity indicators (including monetary aggregates, domestic and cross-border credit aggregates, money market rates, stock market volatility, retail lending rates).

Recent research has put particular emphasis on cross-border credit availability, which has been a significant source of funding for many economies and, as it turns out, can be an important source of vulnerability of the banking sector to a global financial crisis. In the context of the global financial crisis, ample global liquidity has been identified as a potentially important factor in the build-up of the pre-crisis financial imbalances (e.g. Borio et al., 2011). In the context of the 2007-2008 global financial crisis, the global lack of liquidity has been identified as a potentially important factor resulting from the accumulation of imbalances in the period before the crisis (Borio, 2008). Eickmeier, Gambacorta and Hofmann (2014) find that global credit supply conditions eased markedly and contributed considerably to global financial developments between the mid-1990s and 2007, in particular in the years just before the global financial crisis. These measures take into account the increasing role of liquidity created by emerging market economies. But studies concerning the impact of liquidity on emerging countries are rather scarce. Lastly, the IMF (2010) examines the link between capital investment flows and growth in global liquidity in emerging countries. The results indicate that global liquidity is positively correlated with equity investments. On the other hand, Chudik and Fratzscher (2011) emphasize the role of changes in risk appetite (evidenced by VIX index) and of the monetary policy (estimated by the change in the interest rate market) in the global liquidity, and they find that liquidity problems influence advanced economies more than emerging economies.

To provide a sense of global liquidity diversity, Figure 1 shows domestic and cross-border credit trends for advanced and emerging countries. The total bank credit remains relatively low in these countries. However, domestic credit in both Latin America and Asia has recently grown faster than in Europe and the United States. This is in line with the observation that credit tends to grow strongly within countries such as China, which is experiencing a domestic credit boom. This stands in contrast to the sharp collapse in emerging Europe.

In addition, the literature also highlights short-term and long-term interest rates as indicators of global financing conditions, as well as implied market volatility (VIX) as a key measure of investors' willingness to take risks in the financial market. Qian, Tam and Zhang (2014) find that market declines and market volatility increase liquidity commonality. Brunnermeier and Pedersen (2009) present the research on liquidity spirals as a result of shocks in assets' market liquidity. They point out that the probability of liquidity problems increase when market declines, negatively affecting traders' assets. Negative interactions between funding liquidity and the market may cause a sudden sale of assets by financial institutions. Such measures may encourage liquidity providers to increase the spread and increase the value of collateral. Creditors may also be less willing to provide financing for volatile and insolvent partners. The market participants' willingness to provide liquidity depends on their risk preferences. The cyclical changes in risk appetite can amplify global liquidity by intensifying liquidity shortages and surges. The role of financial markets in the economy largely determines its financial structure. The financial market in the market-oriented financial systems is a highly competitive banking sector and it is the alternative financing. However, in the banking-oriented system, the banks play a major role in the 
capital mobilization. Therefore, our study aims to explain the interactions between liquidity and financial market risk.

\section{Figure 1}

Global bank credit aggregates, by borrower region. At constant end-Q2 2011 exchange rates
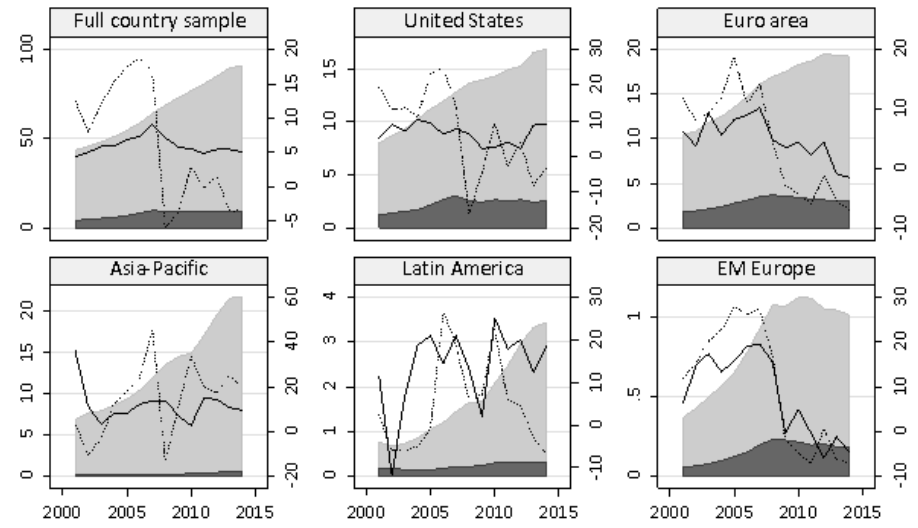

\begin{tabular}{|ll|}
\hline Domestic credit (level) a) & Cross-border credit (level) a) \\
\hline Domestic credit (yoy) b) & Cross-border credit (yoy) b) \\
\hline
\end{tabular}

The shaded areas indicate total domestic and cross-border bank credit to non-bank borrowers (including governments), expressed in US dollars at constant end-2010 exchange rates. The solid lines show domestic and cross-border credit growth. The first graph "Full country sample" depicts aggregates for a sample of 51 countries. a) In trillions of US dollars (lhs). b) In percent (rhs).

Sources: IMF, International Financial Statistics; BIS international banking statistics; BIS calculations.

The importance of foreign concentration in the banking industry is further amplified by the fact that the CEE economies are generally similar to the continental bank-based system, leading to an increased importance of macroeconomic and structural influences. Foreign ownership of banks can have substantial positive effects on the banks such as new capital, know-how transfer, technology and stimulating efficiency in the banking sector. However, if costs are too high compared to benefits, foreign banking groups might opt not to support failing subsidiaries. Barth concludes that foreign ownership can have "two faces" for the CEE banking systems: additional challenges in terms of development but also an improvement of the supervision level (Barth 2004, p. 20). Figure 2 shows the comparison of the liquidity ratio measured by the banks' loans over total assets in developed and developing countries.

\section{Figure 2}

The comparison of liquidity (credit to total assets) in developed and emerging European countries

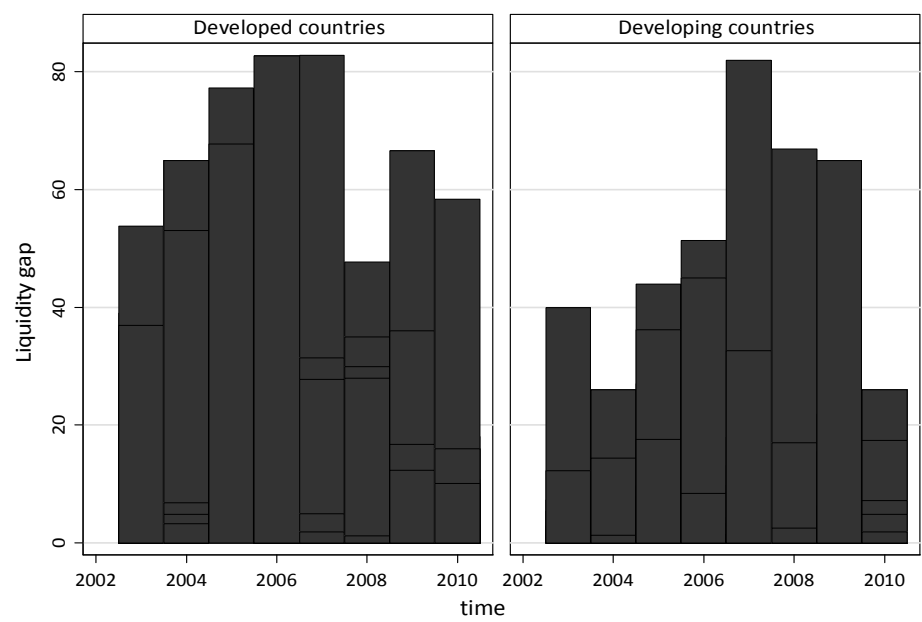

This figure shows time-series plots of yearly averages of the liquidity ratio (measured by the banks' loans over total assets) in banking sectors over the time period from 2001 to 2010 .

Source: Bankscope. 
Figure 2 shows an increase in liquidity before the 2007-2008 crisis, especially in emerging/ developing countries. Excess liquidity has an impact on emerging economies as if it were a domestic monetary shock. The sharp decline of liquidity was observed in 2008, mainly in developed countries. But the lack of liquidity in emerging countries in the last year - $2010-$ seems to be problematic.

A multitude of used methods has been verified in mature economies, which does not allow to draw clear conclusions for emerging countries. Therefore, it leads us to the following hypotheses:

- $\quad$ The current level of the country development determines global liquidity.

- Macroeconomic and monetary policy is associated with global liquidity, but only in emerging economies.

- Global banks play a significant role in the liquidity channel of a country's financial system.

In this respect, we estimate various factors affecting liquidity in advanced and emerging economies. As a measure of liquidity, we apply the bank credit supply. We also use a multiple panel regression that aggregates the determinants of global liquidity into three groups: local (macroeconomic and monetary policy), global, and financial market drivers.

\section{CHARACTERISTICS OF THE MAIN LIQUIDITY DETERMINANTS AND TRANSMISSION CHANNELS}

Conditions of banking liquidity are related to interactions between three major drivers: (i) local factors (macroeconomic and monetary policy); (ii) global factors; and (iii) financial market factors that take into account risk appetite of financial market participants. All these factors change and interact in complex ways.

\subsection{Local factors (macroeconomic and monetary policy)}

As macroeconomic determinants, we used GDP growth and inflation rate. Macroeconomic factors form an environment in which the financial system passes the test of dealing with imbalances and market shocks. This situation reduces the likelihood of liquidity problems and bankruptcy of financial intermediaries. Higher inflation could limit the supply of credit, but faster growing economies could have greater demand for credit. An environment of low inflation and interest rates in the economy results in bigger competition among banks. It could reduce the opportunity for banks to get appropriate prices for their lending and deposit activity.

The second determinant is the monetary policy factor. This is a very interesting variable to study because market developments require the central bank action (monetary policy instruments) that boosts or reduces liquidity of the banking system. High liquidity in the banking system would result in significant banking credits. But low liquidity causes a freeze on money markets and individual banks' problems with liquidity funding. As the recent crisis has shown, the impact of monetary policy instruments is different from expected. The financial system does not react properly. Loosening of monetary policy does not start either a wave of investment or lending. We used the annual growth rate in money supply (M2) to account for this.

\subsection{Global factors}

Following Adrian and Shin (2010) findings, we use the leverage of global banks that is facilitated by cross-border bank lending. Relative differences between global conditions prevailing in emerging and advanced countries will be captured by the index of financial globalization. 
Its effect depends on the correlation with the external financial crisis. In the case of a positive correlation, globalization will increase the bank lending.

\subsection{Financial market drivers}

The bank lending depends not only on monetary policies and interest rate changes, but also, crucially, on the size of risk appetite. Generally, periods of rising risk appetite tend to be associated with wholesale funding, the expensive credit policy in the banking sector. Liquidity shortages can cause critical problems with funding and concerns about liquidity and solvency. Market participants reduce leverage because of poor market liquidity and rising counterparty risk. The banks' behavior is an important acceleration mechanism for positive/negative liquidity shocks. Adrian and Shin (2010), Adrian et al. (2013) pointed to the close association between the leverage and credit supply of investment banks and the VIX index of the implied volatility of options in S\&P 500 index. Stahel (2003) investigates country, industry, and global liquidity of individual stocks, and analyzes their implications for the pricing of financial assets in an international framework for a sample from the United States, the United Kingdom, and Japan covering the period from 1980 to 2001 . He proposes liquidity measures based on daily return and trading volume data and suggests that individual stock liquidity exhibits itself within countries and industries and co-moves globally. The asset pricing analysis suggests that expected stock returns are cross-sectionally related to the sensitivity of returns to shocks in global liquidity.

Figure 3 illustrates the combined use of price and quantitative liquidity measures, showing indicators of credit to banks and non-banks together with the VIX index as a proxy for risk appetite. The growth in global bank credit exhibits boom-bust cycles that correspond to episodes of financial crisis, identified by low risk appetite and high volatility of the VIX index. The changes in bank credit and risk appetite proxies appear consistent with the global liquidity cycle. In context of abundant global liquidity and decline in risk aversion, strong investment inflows searching for higher yield would likely have an impact on exchange rate and assets prices in emerging markets (Karkowska, 2003).

Figure 3

VIX index as risk appetite and credit to banks and non-banks

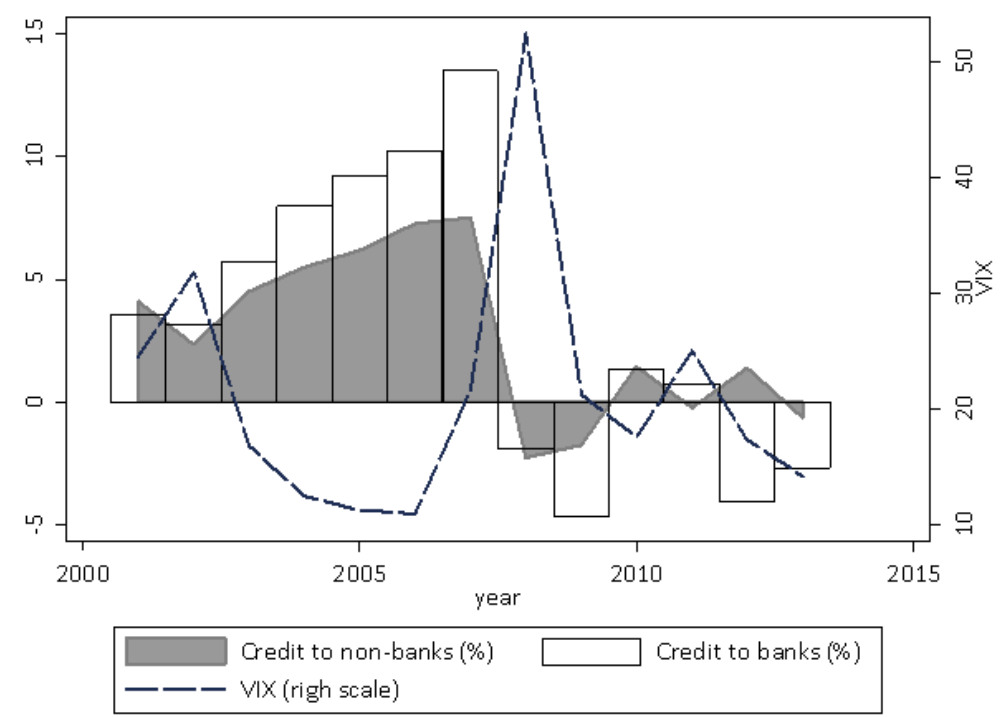

The shaded areas indicate credit to non-banks and banks (growth rate in percent, lhs) and VIX volatility index (in percent, rhs). Sources: own study based on Thomson Reuters Eikon; BIS locational banking statistics by residence. 
The other market variable is the growth in the stock exchange capitalization. To capture the role of the stock equity and trading, we use the total value of shares traded during the period divided by the average market capitalization. We emphasize that the capital market is an important source of crisis impulses transmission. According to Garleanu and Pedersen (2011), the difference in market liquidity between high margin and low margin assets increases a phenomenon that is often referred to as flight to quality.

Finally, our model also predicts that lending rises as the interest rate spread increases in the interbank market. We do not take into account the difference between the lending rate and the deposit rate (the lending rate is the rate charged by banks on loans to the private sector and the deposit interest rate is the rate offered by commercial banks on three-month deposits) presented by IMF International Financial Statistics but the interbank market liquidity spread is measured as a change in BID - ASK spread in $\mathrm{O} / \mathrm{N}$ transactions.

\section{EMPIRICAL ANALYSIS}

\subsection{Sample and Variable Definitions}

We perform a comparative analysis of determinants of global liquidity in emerging and developed countries. In recent studies (Bruno and Shin, 2012; Domanski et al., 2011), credit as the ratio of banking assets is proposed as the liquidity measure. This test is an extension of the study conducted in a group of 19 countries in the world and examines the effects of macroeconomic and systemic factors on the level of global liquidity (Karkowska, 2013a, pp. 311-322). From the financial stability perspective, changes in banks' funding practices suggest that credit is a suitable measure of liquidity conditions (dependent variable). Factors determining liquidity are aggregated into three groups (independent variables): i/ local factors (GDP growth, Inflation Rate, Money Supply) ii/ global factors (Leverage of Global Banks, Globalization Index), iii/ financial market drivers (VIX index of the implied volatility, $\mathrm{O} / \mathrm{N}$ liquidity spread, and Market Capitalization in Stock Market). The leverage of global banks is calculated as total assets to equity in the sample of the most important banks operating in emerging markets. The list of them is presented in Appendix 2.

The regression panel model estimates the impact of different determinant on global liquidity. The results should explain which of the liquidity drivers are most important.

Our sample for the panel estimation draws on data from 42 countries, encompassing both developed economies and emerging/developing economies over the period from 2000 to 2011 . Our dataset covers a number of European banks that are involved in traditional and investment activities. The set of countries includes: a/ 12 CEE economies (Bulgaria, the Czech Republic, Estonia, Hungary, Latvia, Lithuania, Poland, Romania, Slovenia, Slovakia, Turkey, Ukraine), b/ 10 emerging/developing economies (Argentina, Brazil, Chile, Mexico, Paraguay, Peru, Philippines, Thailand, Tunisia, Uruguay) and c/ 20 developed economies (Australia, Austria, Belgium, Canada, Denmark, Finland, France, Germany, Iceland, Italy, Japan, the Netherlands, New Zealand, Norway, Portugal, Spain, Sweden, Switzerland, the UK, the USA). The division into samples should indicate differentiation factors affecting liquidity.

The model estimation has been preceded by the correlation analysis (Table 1). The global liquidity is significantly correlated with the most of all explanatory variables. But the relationships with all variables (which include macroeconomic and monetary variables, and global and financial markets) appear rather mixed. In the panel data model estimation we find that the impact of individual factors determining liquidity is affected by the group of country. 
Table 1

Correlations matrix

\begin{tabular}{|c|c|c|c|c|c|c|c|c|c|}
\hline & LIQUIDITY & GDP & INF & MONEY & LEVERAGE & GLOBAL & VIX & STOCK & SPREAD \\
\hline LIQUIDITY & 1.0000 & & & & & & & & \\
\hline GDP & $0.0321^{*}$ & 1.0000 & & & & & & & \\
\hline INF & 0.0778 & -0.0022 & 1.0000 & & & & & & \\
\hline MONEY & $0.1438^{*}$ & -0.0470 & -0.0420 & 1.0000 & & & & & \\
\hline LEVERAGE & $0.0438^{* *}$ & $0.0029^{*}$ & $-0.0013^{*}$ & $0.1229^{*}$ & 1.0000 & & & & \\
\hline GLOBAL & $0.1239^{* *}$ & $0.047^{* *}$ & $0.0432^{* *}$ & -0.0242 & 0.0091 & 1.0000 & & & \\
\hline VIX & $-0.1117^{* *}$ & $0.0422^{*}$ & $0.0317^{*}$ & $-0.0303^{*}$ & $0.0737^{*}$ & $0.2303^{*}$ & 1.0000 & & \\
\hline STOCK & $0.0292^{*}$ & $0.012^{* *}$ & $-0.0139^{*}$ & $-0.1399^{*}$ & $0.0233^{*}$ & -0.0094 & 0.0200 & 1.0000 & \\
\hline$\triangle$ SPREAD & $-0.1847^{* *}$ & $0.0014^{*}$ & $-0.0243^{*}$ & $0.1298^{*}$ & $-0.018^{*}$ & $-0.2189^{*}$ & 0.0212 & $0.2438^{*}$ & 1.0000 \\
\hline
\end{tabular}

Notes: This table reports the correlation coefficients of variables for the time-series regressions in this study. LIQUIDITY equals banks' lending over total assets; GDP equals annual growth of real GDP; INF equals changes in inflation rate; MONEY equals annual broad money supply to GDP; LEVERAGE equals total assets to equity in global banks; GLOBAL equals the index of financial globalization; VIX equals VIX index of implied volatility; STOCK - stock markets turnover ratio (value traded/capitalization); $\triangle \mathrm{SPREAD}$ equals (ASK price - BID price) in O/N transactions. ${ }^{*},{ }^{* *},{ }^{* * *}$ significance level at $10 \%, 5 \%$ and $1 \%$.

Source: Bankscope, IMF, Thomson Reuters Thomson Reuters Eikon, Kaufman, 2009.

The study of the effect of each factor on the liquidity is carried out in two steps. Firstly, the estimation of the model was performed on the panel data for three separate groups of countries: i) Central and Eastern European countries (CEE), ii) emerging/developing countries in the world, iii) developed countries. In the second phase, testing was performed on the data for each individual country of CEE.

To test our hypotheses, we apply a two-step GMM robust estimator for data spanning the years 2000-2011 on individual banks. The two-step GMM estimator (Arellano and Bond, 1991; Blundell and Bond, 1998) may impose a downward or upward bias in standard errors due to its dependence on the estimated residuals, which may lead to unreliable asymptotic statistical inference (Bond, 2002). To test the validity of the instruments, we implemented the Sargan specification test, which, under the null hypothesis of valid moment conditions, is asymptotically distributed as chi-square (Arellano and Bond, 1991; Blundell and Bond, 1998). All regression parameters are provided with the level of significance, which should facilitate the interpretation of results. The final version of the model is given by equation (1) below:

$$
y_{n, j, t}=y_{n, j, t-1}+\sum_{k=1}^{n} \alpha_{k} x_{j, t}+\sum_{k=1}^{n} \beta_{k} z_{j, t}+\sum_{k=1}^{n} y_{k} u_{j, t}+\theta_{t} T_{t}+\mu_{j}+\varepsilon_{j, t},
$$

where:

$y_{n, j, t}$ is the individual bank's loans normalized by total assets, and indicates the selected dependent variables for bank $n$, in $j$-th country, observed in $t$ period;

$x_{j, t}$ is a vector of explanatory macroeconomic and monetary variables, i.e.:

$x_{j, t}=[G D P, I N F$, Money $]$,

where:

$G D P$ - real GDP growth, as a macroeconomic/ procyclical factor;

$I N F$ - change in inflation rate;

Money - equals annual broad money supply to GDP;

$z_{j, t}$ is a vector of explanatory global variables, i.e.:

$z_{j, t}=[$ Leverage, Global $]$, 
where:

Leverage - total assets to equity in global banks;

Global - the index of financial globalization;

$u_{j, t}$ is a vector of explanatory financial market variables, i.e.:

$u_{j, t}=[\Delta$ Spread, VIX, Stock $]$,

where:

$\Delta$ Spread - change in BID ASK interest spread in $O / N$ transactions on the interbank market, VIX - volatility index VIX, as a market factor;

Stock - stock markets turnover ratio (value traded/capitalization);

$T_{t}-$ is a vector of year dummies;

$\mu_{j}-$ is an unobservable time-invariant country effect.

The sample covers 42 countries for which statistical data was available from 2000 to 2011 . Descriptive statistics of model variables is presented in Appendix 1.

The model (1) took into consideration two specification tests suggested by Arellano and Bond (1991). The first one is Hansen's test, which checks the overall validity of the instruments. The other examines the hypothesis of absence of a second-order serial correlation in the firstdifference residuals (AR2). In the models, this hypothesis is always rejected. The first-order serial correlation (AR1) is present in the models.

To analyze the differences across countries in sensitivity of banking liquidity to different determinants for each CEE country, a regression model (2) was estimated. The final version of the model reads as follows:

$$
\begin{aligned}
y_{i, t}= & \beta_{0}+y_{i, t-1}+\beta_{1} \text { GDP }_{j, t}+\beta_{2} \text { INF }_{j, t}+\beta_{3} \text { Money }_{j, t}+\beta_{4} \text { Leverage }_{j, t}+ \\
& +\beta_{5} \text { Global }_{j, t}+\beta_{3} \text { VIX }_{j, t}+\beta_{7} \text { SSpread }_{j, t}+\beta_{8} \text { Stock }_{j, t}+\varepsilon_{t},
\end{aligned}
$$

where:

$\beta$ - estimated coefficient, $\varepsilon_{t}-$ white noise error term.

Several specification tests of the model (2) were run to select the best model for each country. The following tests were applied: White's test of heteroskedasticity, Jarque-Bera's test of normality distribution of disturbances and other parameters, e.g. measures of goodness of fit (adjusted R-squared).

\section{EMPIRICAL RESULTS}

We investigate the impact of a set of prices and quantity variables on liquidity for a sample group of 22 emerging economies especially from Central and Eastern Europe and 20 advanced countries. As described above, the first empirical exercise tests how global liquidity is affected by three groups of determinants for different categories of countries. Our main comparison is between emerging and advanced countries.

The estimation results for panel data were presented in Table 2 for the CEE countries, in Table 3 for emerging/developing countries, and in Table 4 for advanced countries. Table 5 presents the sensitivity estimation for individual CEE countries.

Column (1) is the specification that includes the variables of macroeconomic and monetary policy drivers. Column (2) is the specification that includes the variables of global drivers. Column (3) is the specification that includes the variables of financial market determinants. Column (4) is the specification that includes all variables. Columns (5-7) are the specification that includes the 
variables of individual most significant drivers for a particular group of countries. In the study, a one year lagged variable was also included.

The estimations for the CEE countries in Table 2 enter with the predicted signs, which highlight the role of global drivers. Particularly notable are the variables LEVERAGE as the banks' leverage and GLOBAL (globalization index). The interdependence between them and global liquidity is positive and highly significant in every specification. Thus, an increase of the leverage and the presence of global banks in the CCE economies lead to an acceleration of liquidity.

Higher money supply and GDP, proxying for high economic growth conditions, are positively associated with liquidity, whereas these variables are not statistically significant in every specification. The liquidity has been driven by financial market factors mostly negatively.

The results for the rest of emerging/developing countries in Table 3 are similar to the findings for the CEE economies. The main liquidity drivers are located in the global environment, but their impact on global liquidity is smaller than in the Central and Eastern European countries.

Our results for the group of developed countries (Table 4) are broadly in line with previous studies. The financial market gains importance, and the fire sales effects fulfilled the function of improving global liquidity. The results of our estimation emphasize the compatibility with Qian, Tam and Zhang (2014), who find that market declines and market volatility increase liquidity commonality. The liquidity fluctuations are significantly affected by the size of market capitalization, which is particularly evident in countries with a long capital market tradition. The trend is as follows: a growth in market capitalization is accompanied by increases in bank lending, and vice versa. In turn the interbank money market started to play a particular role. The following relations have been observed: the $\mathrm{O} / \mathrm{N}$ spread increases are associated with decreases in liquidity. This highlights that the money market is an important source of funding for credit and liquidity in commercial banks.

The activities of central banks remain without significant effects on changes in lending policies of commercial banks. The macroeconomic drivers like GDP impact liquidity slightly, confirming pro-cyclical nature of global liquidity. This finding of a slight effect of the macroeconomic and monetary policy on global liquidity contrasts with Artus and Virard's (2010) results. Our results show that when the global liquidity sample is split into emerging versus advanced countries, economic growth and loosening of monetary policy are significantly associated, but only in emerging economies. This set of results also provides an important insight into Rüffer and Stracca's (2006) result that banks' lending is shielded from the monetary policy because of their ability to freely access alternative sources of funds.

Finally, we observe a significant role of global drivers (specification 2) and marginal risk volatility in financial markets (specification 4). The individual approach presented in Table 5 confirms the previous prediction. The financial market liquidity channel showed no significant effect. The money market liquidity factor expressed as the spread on $\mathrm{O} / \mathrm{N}$ transactions has not given an unequivocal interpretation. The impacts of GDP growth and inflation determinants differ from country to country, which is likely to be affected by the structure of the banking system and individual banks' strategies. Globalization drivers impact liquidity mostly in the Baltic economies (Latvia, Lithuania and Estonia), Poland and Romania, which confirms the previous literature review. These emerging countries have the largest share of global banks in their banking sectors. The reported results are similar to the analyses of liquidity estimates by Bruno and Shin (2014). They investigate global factors associated with bank capital flows and formulate a model of the international banking system where global banks interact with local banks. 


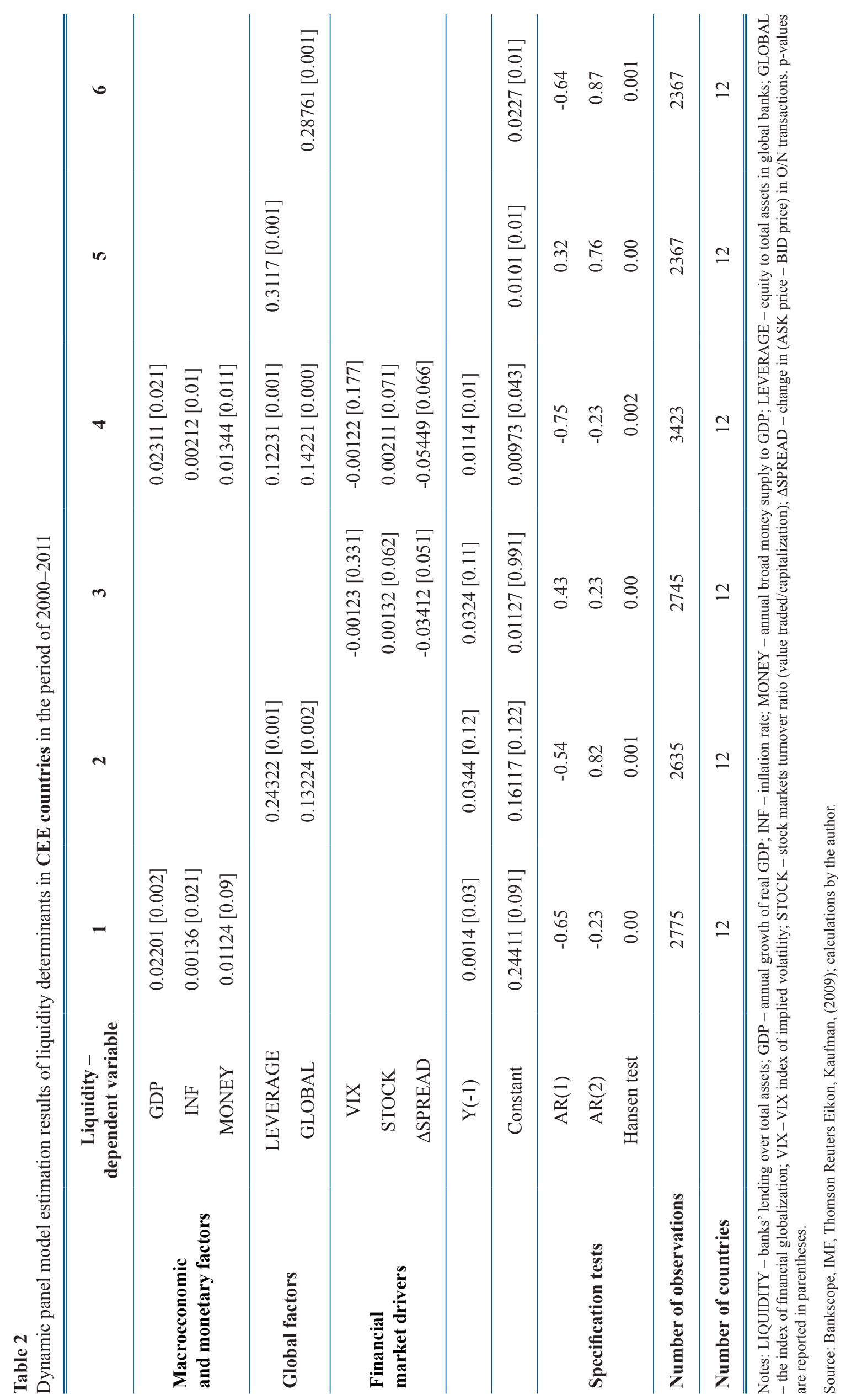




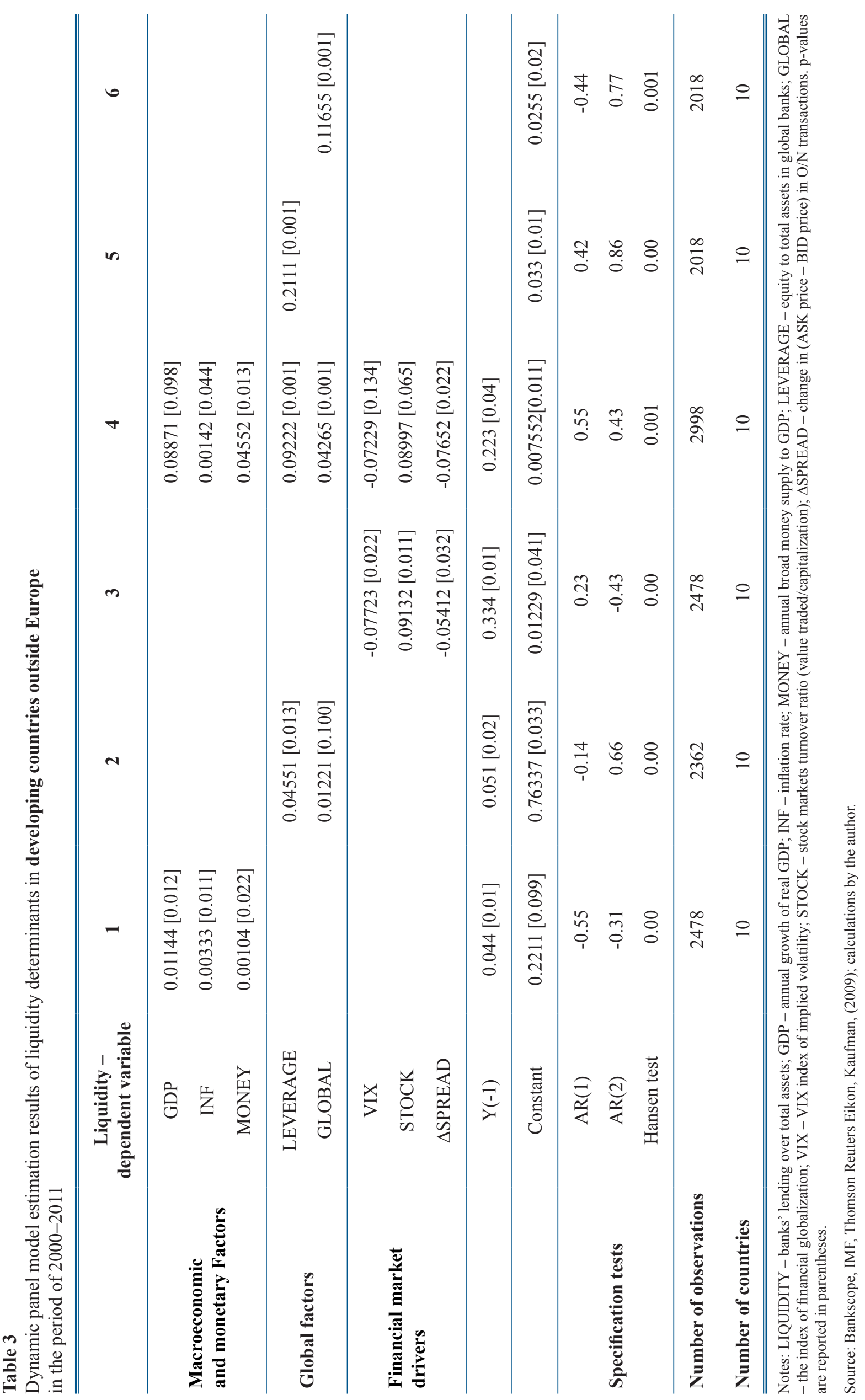




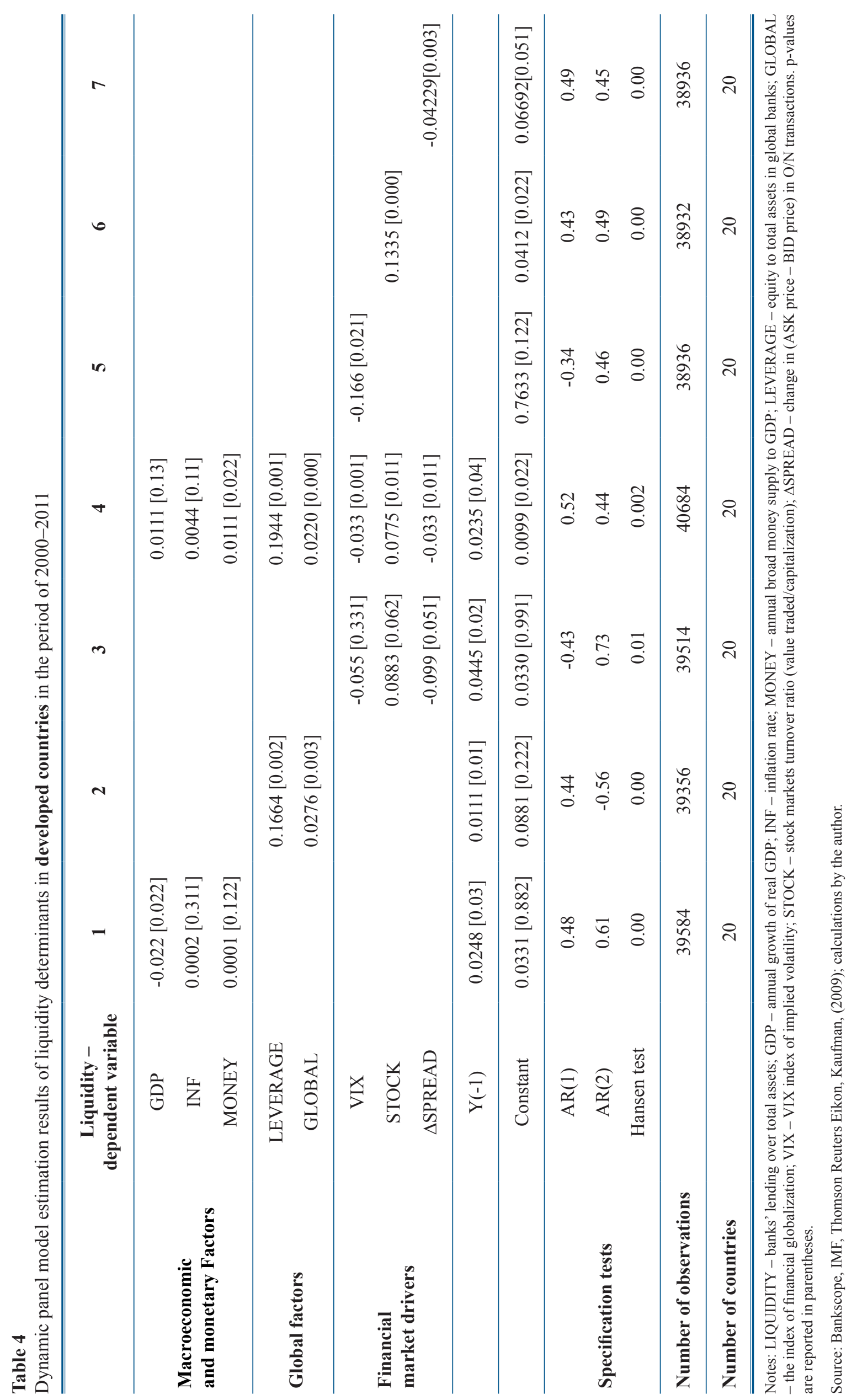




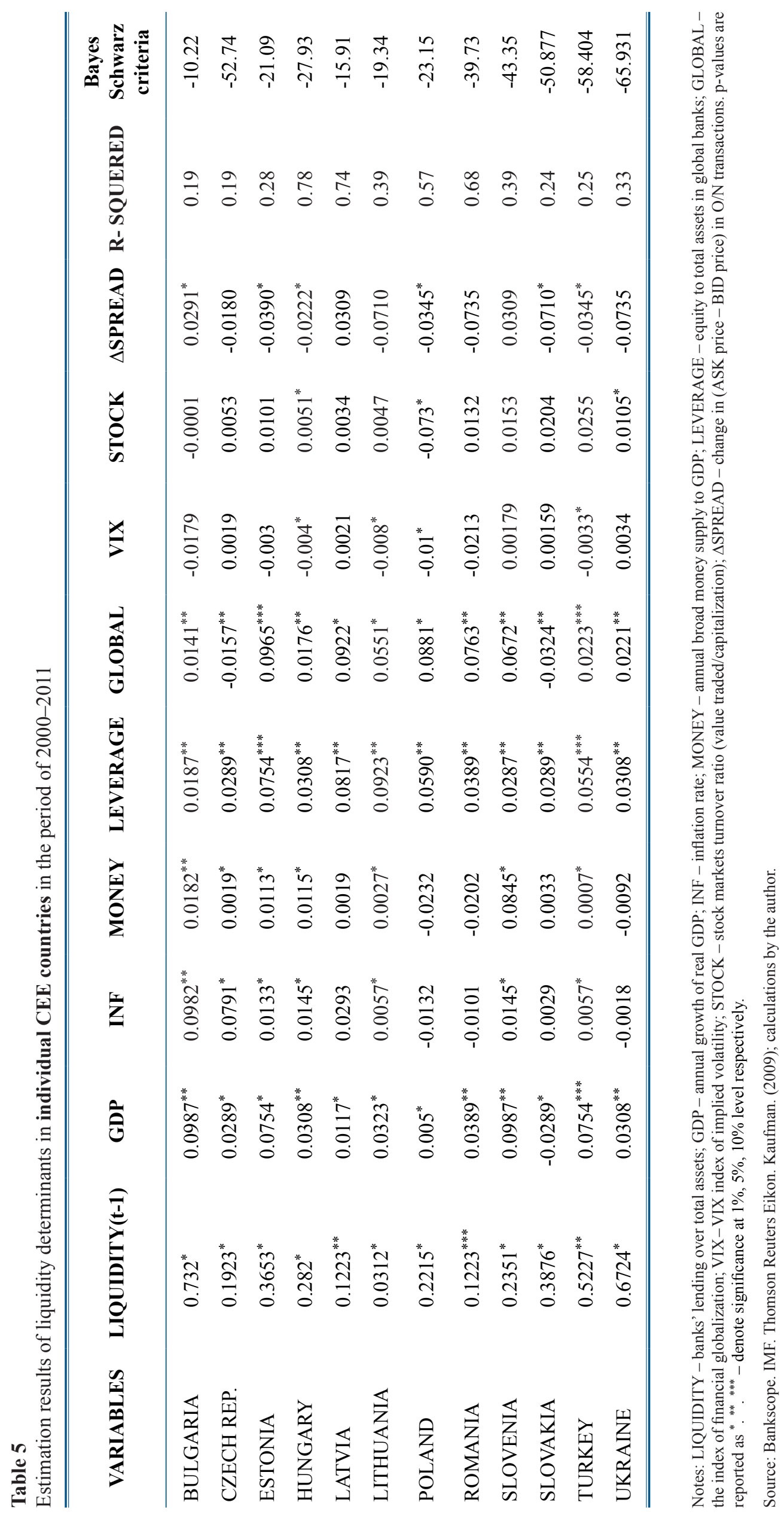




\section{CONCLUSIONS}

Overall, our results provided some interesting new insights into the mechanisms that determine global liquidity in different groups of economies: emerging and advanced. Our findings confirm research from former studies on global liquidity, but also contrast it, showing that when the global liquidity sample is split into emerging versus advanced countries, economic growth and loosening of the monetary policy are significantly associated, but only in emerging economies. This set of results also provides an important observation that banks' lending in advanced countries is shielded from the monetary policy because of their ability to freely access alternative sources of funds. Moreover, we identify a negative relation between the financial market drivers and banks' lending. Our findings reinforce the argument in Borio and Disyatat (2011) and Gourinchas and Obstfeld (2012) on the importance of gross capital flows between countries in determining financial conditions.

The main empirical results of our paper indicate that at the global level drivers may convey useful information on global liquidity in emerging countries. We have highlighted the role of global financial banks in local bank funding. Global factors remain more important than local factors in explaining the bank liquidity in developing countries.

The study confirmed the conjecture about the diversity of global liquidity determinants across emerging and advanced countries. As global liquidity is a major component of a country's economic growth, our study also has implications for economic policies. Our findings open up a number of ways for future study, both theoretical and empirical, on liquidity in emerging economies.

\section{References}

Adrian T., Moench E., Shin H.S. (2013) Leverage Asset Pricing, FRB of New York Staff Report No. 625.

Adrian T., Shin H.S. (2010) Liquidity and Leverage, Journal of Financial Intermediation.

Anderson J. (2007) More stable than you think. UBS Investment Research, Asian Focus, 22 January.

Arellano M., Bover O. (1995) Another Look at the Instrumental Variable Estimation of Error-Components Models, Journal of Econometrics 68, no. 1: 29-51.

Arellano M., Bond S. (1991) Some Tests of Specification for Panel Data: Monte Carlo Evidence and an Application to Employment Equations, Review of Economic Studies 58, no. 2: 277-297.

Artus P., Virard M.-P. (2010) La liquidité incontrôlable; Qui va maîtriser la monnaie mondiale? Pearson Education.

Barth J., Caprio G., Levine R. (2004) Bank regulation and supervision: what works best? Journal of Financial Intermediation 13: 205-248.

Bernanke B. (2005) The global saving glut and the U.S. current account deficit. Speech at the Sandridge Lecture, Richmond, 19 March 2005.

Borio C., McCauley R., McGuire P. (2011) Global credit and domestic credit booms. BIS Quarterly Review, September 43.57.

Borio C., Disyatat P. (2011) Global imbalances and the financial crisis: Link or no link? BIS Working Paper 346.

Borio. C. (2008) The financial turmoil of 2007-?: A preliminary assessment and some policy considerations, BIS Working Paper, 251.

Brunnermeier. M.K., Pedersen L.H. (2009) Market Liquidity and Funding Liquidity, Review of Financial Studies 22: 2201-2238.

Bruno V., Song Shin H. (2014) Cross-Border Banking and Global Liquidity, BIS Working Papers, No 458.

Bruno. V., Shin. H.S. (2012) Capital flows and the risk-taking channel of monetary policy. Mimeo. Princeton University.

Chudik, A., Fratzscher, M. (2011) Identifying the global transmission of the 2007-2009 financial crisis in a GVAR model, European Economic Review 55: 325-339.

Ciccarelli, M., Maddaloni A., Peydró J.-L. (2010) Trusting the Bankers: A New Look at the Credit Channel of Monetary Policy. ECB Working Paper, 1228.

D’Agostino A., Surico. P. (2009) Does global liquidity help to forecast U.S. inflation? Journal of Money. Credit and Banking. 412-3: 479-489.

Darius R., Radde S. (2010) Can global liquidity forecast asset prices? IMF Working Paper, WP/10/196. August. 
Domanski D., Fender I., McGuire P. (2011) Assessing global liquidity. BIS Quarterly Review. December 2011: 57-71.

Eickmeier S., Gambacorta L., Hofmann B. (2014) Understanding global liquidity, European Economic Review, 68(2014): 1-18.

Garleanu N., Pedersen L.H. (2011) Liquidity market: Asset Pricing, Risk, and Crises, Cambridge University Press.

Gourinchas P.O., Obstfeld M. (2012) Stories of the Twentieth Century for the Twenty-First, American Economic Journal: Macroeconomics, 4(1): 226-65.

IMF (2010) Global liquidity expansion: Effects on "receiving" economies and policy response options. IMF Global Financial Stability Report. April. Chapter 4: 327-354.

Karkowska R. (2003) Zjawisko umacniania sie złotego na rynku walutowym w Polsce, Bank i Kredyt, nr 9: 24-31.

Karkowska R. (2013) Analyzing Systemic Risk in CEE Markets in 2007-2008 Financial Crisis, Management 8 (1): $37-47$.

Karkowska R. (2013a) Siła oddziaływania czynników makroekonomicznych i systemowych na poziom globalnej płynności, Prace naukowe Uniwersytetu Ekonomicznego we Wrocławiu, nr 305.

Kaufmann D., Kraay A., Mastruzzi M. (2009) Governance matters VIII: aggregate and individual governance indicators, 1996-2008. Policy Research Working Paper, No. 4978, The World Bank.

Kose M., Otrok C., Whiteman C. (2003) International business cycles: world, region, and country specific factors. Am. Econ. Rev. 93(4): 1216-1239.

Qian X., Tam L., Zhang B. (2014) Systematic liquidity and the funding liquidity hypothesis, Journal of Banking \& Finance, 45: 304-320

Rüffer R., Stracca, L. (2006) What is global excess liquidity, and does it matter? European Central Bank Working Paper Series 696.

Stahel Ch.W. (2003) Is there a Global Liquidity Factor? Department of Finance, Fisher College of Business, The Ohio State University. 


\section{APPENDIX}

\section{Supplementary information - descriptive statistics on the data}

\begin{tabular}{lccc}
\hline \multicolumn{1}{c}{ Variable } & Mean & Standard Deviation & $\begin{array}{c}\text { Supplementary information on } \\
\text { the data }\end{array}$ \\
\hline Liquidity & .5113537 & .133808 & Bankscope, 2012 \\
GDP & 0.03453 & .03378 & IMF, national sources) \\
Inflation & 0.03349 & .13579 & IMF, national sources) \\
Money & .352987 & 3.3834 & IMF, national sources) \\
Leverage & .1387344 & 3.1284 & Bankscope 2012 \\
Globalization index & 74.9754 & 13.934 & Kaufmann, (2009) \\
VIX & 23.8731 & 8.9733 & Thomson Reuters Eikon \\
Stock & 34.1187 & 9.9332 & S \& P Global Stock Markets \\
\hline $\begin{array}{l}\text { SPREAD (BID-ASK spread } \\
\text { on Overnight transaction) }\end{array}$ & .05133 & 4.9853 & Factbook data \\
\hline
\end{tabular}

The table provides a descriptive overview of the data. We report the results for the liquidity determinants as well as further variables used in this study. It reports the source of data, number of observations (N), Mean and Standard Deviation.

Notes: LIQUIDITY - banks' lending over total assets; GDP - annual growth of real GDP ; Inflation - inflation rate; MONEY - annual broad money supply to GDP; LEVERAGE - equity to total assets in global banks; GLOBAL - the index of financial globalization; VIX - VIX index of implied volatility; STOCK - stock markets turnover ratio (value traded/capitalization); SPREAD - (ASK price - BID price) in O/N transactions. Source: Bankscope, IMF, Thomson Reuters Eikon, Kaufman, 2009; calculations by the author. 
2. List of globally important banks used in the analysis

\begin{tabular}{|c|c|c|c|c|c|}
\hline No & Bank name & Country name & $\begin{array}{c}\text { Average } \\
\text { Assets }\end{array}$ & Leverage & $\begin{array}{c}\text { Liquid } \\
\text { Assets/ } \\
\text { Deposits }\end{array}$ \\
\hline 1 & Deutsche Bank AG & GERMANY & 2380301056 & 1.50 & 22.45 \\
\hline 2 & Mitsubishi UFJ Financial Group & JAPAN & 2108421098 & 6.97 & 45.98 \\
\hline 3 & Industrial \& Commercial Bank of China & CHINA & 1622987723 & 6.09 & 40.39 \\
\hline 4 & BNP Paribas & FRANCE & 1679249920 & 2.63 & 45.65 \\
\hline 5 & JP Morgan Chase \& Co. & US & 1594249120 & 6.09 & 45.98 \\
\hline 6 & UBS AG & SWITZERLAND & 1414399360 & 2.13 & 73.01 \\
\hline 7 & Société Générale & FRANCE & 1394032768 & 1.90 & 32.10 \\
\hline 8 & Royal Bank of Scotland & UNITED KINGDOM & 1376651008 & 3.81 & 26.11 \\
\hline 9 & Bank of America Corp. & US & 1176754233 & 3.55 & 35.60 \\
\hline 10 & HSBC Bank plc & UNITED KINGDOM & 849587264 & 4.90 & 48.56 \\
\hline 11 & Raiffeisen Centrobank AG & AUSTRIA & 849587264 & 5.33 & 20.11 \\
\hline 12 & ING Bank & NETHERLANDS & 669304384 & 5.64 & 63.08 \\
\hline 13 & Crédit Agricole S.A. & FRANCE & 590790528 & 6.97 & 87.15 \\
\hline 14 & Lloyds TSB Bank Plc & UNITED KINGDOM & 527250080 & 3.51 & 16.49 \\
\hline 15 & Banco Bilbao Vizcaya Argentaria SA & SPAIN & 482156192 & 6.09 & 45.98 \\
\hline 16 & Banco Santander SA & SPAIN & 477009120 & 8.48 & 40.39 \\
\hline 17 & Intesa Sanpaolo & ITALY & 449784192 & 12.27 & 37.46 \\
\hline 18 & Danske Bank A/S & DENMARK & 421235200 & 4.41 & 21.30 \\
\hline 19 & Commerzbank AG & GERMANY & 418591200 & 3.68 & 39.57 \\
\hline 20 & UniCredit & ITALY & 341399968 & 17.39 & 78.44 \\
\hline 21 & KBC Bank & BELGIUM & 296706752 & 4.10 & 28.28 \\
\hline 22 & Allied Irish Banks & IRELAND & 232846304 & 3.55 & 35.6 \\
\hline 23 & Skandinaviska Enskilda Banken AB & SWEDEN & 212935632 & 2.30 & 30.31 \\
\hline 24 & Bank of Ireland & IRELAND & 209866688 & 2.33 & 38.77 \\
\hline 25 & DNB Bank ASA & NORWAY & 208674624 & 5.25 & 27.72 \\
\hline 26 & Svenska Handelsbanken & SWEDEN & 204869488 & 3.50 & 29.05 \\
\hline 27 & Banca Monte dei Paschi di Siena & ITALY & 167369648 & 6.27 & 37.32 \\
\hline 28 & Standard Chartered Bank & UNITED KINGDOM & 157282496 & 8.59 & 24.22 \\
\hline 29 & Swedbank AB & SWEDEN & 138467840 & 3.70 & 46.44 \\
\hline 30 & Nordea Bank AB & SWEDEN & 135370960 & 11.26 & 52.72 \\
\hline
\end{tabular}

The table provides a descriptive overview of the global banks used in this study. We report the indicator analysis of the activities of the largest banks in 2007, based on the Bankscope database.

Source: Author's study. 